\title{
THE IDENTIFICATION OF BRITISH SPECIES OF THE GENUS ENSIS SCHUMACHER (LAMELLIBRANCHIATA)
}

\author{
By N. A. Holme, B.A. \\ Zoologist at the Plymouth Laboratory \\ (Plate I and Text-figs. I-5) \\ INTRODUCTION
}

Winckworth (1932) lists three British species in the genus Ensis Schumacher. Two of these, E. ensis (L.) and E. siliqua (L.), are recorded by Linnaeus in the genus Solen; the third, E. arcuatus (Jeffreys), was considered by Jeffreys (I863) to be a variety of $E$. siliqua. Winckworth has, however, raised it to specific rank, without giving any reasons. In the present paper Winckworth's classification is followed, a note on the validity of the species appearing at the end.

Examination of specimens in various collections has revealed the confusion that has arisen in the identification of the species of Ensis: consequently many records are unreliable. Identification has proved difficult partly on account of a dearth of good illustrations of the three species, and also through the lack of any diagnostic distinguishing characters. Although E. siliqua is illustrated in many works, there are few good drawings of E. ensis, and some (Sowerby, I887, for example) have illustrated E. arcuatus as E. ensis. Forbes \& Hanley (1853) have an engraving of Solen ensis var. magna ( $=E$. arcuatus), but failed to illustrate Ensis ensis.

I am indebted to the following for assistance in obtaining specimens, and for other information: Miss D. Atkins, Messrs H. J. Baal, J. H. Barrett (Warden, Dale Fort Field Centre), H. H. Bloomer, T. E. F. Carr, P. G. Corbin, Major A. A. Dorrien-Smith, Messrs G. R. Forster, N. S. Jones, The Director of the Millport Marine Station, Dr W. J. Rees, Messrs D. P. Sharman, A. G. Southward, G. M. Spooner, J. Thompson, C. C. Wilton-Davies, and the late R. Winckworth.

I am grateful to the Linnean Society of London for allowing me to examine type specimens; and to Dr R. Tucker Abbott, Division of Mollusks, U.S. National Museum, for kindly supplying photographs of Jeffreys' original specimens of $E$. arcuatus.

\section{The Genus ENSIS}

The genus Ensis comprises lamellibranchs with elongate equivalve shells, gaping at either end. The anterior end of the shell is not constricted, and the 
hinge is terminal, having two teeth in the left valve, between which fits the single tooth of the right valve. There is a long external ligament. The two siphons are short and are surrounded by cirri. A fourth pallial aperture is present.

\section{Distinguishing Characters}

In several of the distinguishing characters to be described there is some overlap owing to variation among individuals of a species. Consequently it is often necessary to employ all the available characters before a 'difficult' specimen can be identified.
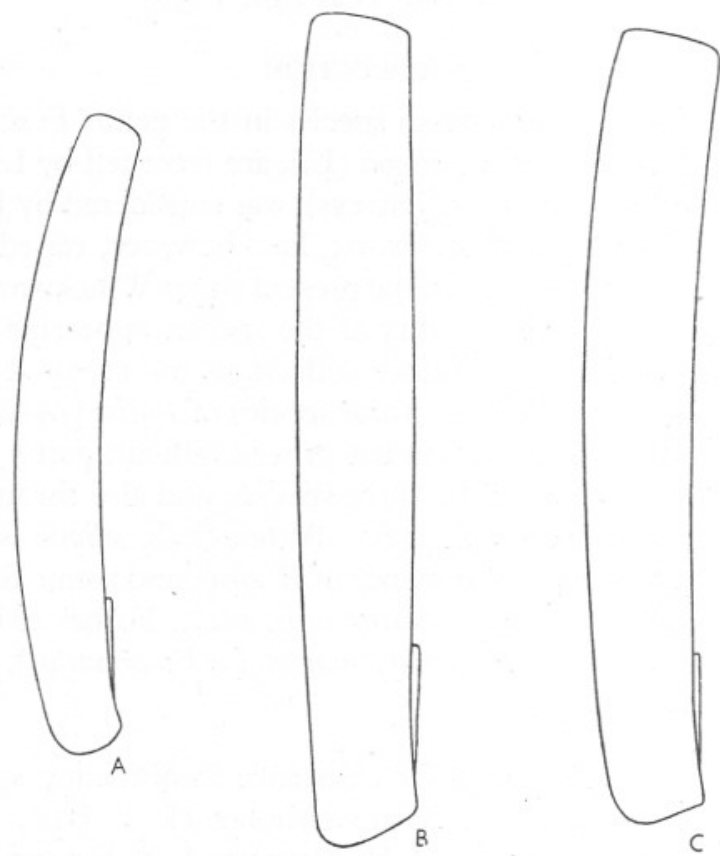

Text-fig. I. Outline of Ensis shells, $\times 3 / 5$. A, E. ensis; B, E. siliqua; C, E. arcuatus.

\section{The Shell}

This remains the primary means of identification, both of the genus and species. The shell of Ensis is elongated along its anterior-posterior axis. Hence the pedal end is morphologically anterior, and the siphonal end is posterior. The long edge bearing the hinge is dorsal.

Length. The length attained by adult specimens differs in the three species. E. siliqua reaches a maximum of $20 \mathrm{~cm}$., while $E$. arcuatus and $E$. ensis attain I5 and $10 \mathrm{~cm}$. respectively. In many populations, however, these lengths are not reached, and Text-fig. 3 gives some indication of the lengths usually encountered. 
Length/breadth ratio. Measurements of shell breadth are made as shown in Text-fig. 2. Results obtained from measurements of about Ioo specimens from different localities are shown in Text-fig. 3 , and summarized in Table I. The mean ratio is 6.80 in $E$. siliqua, 7.18 in $E$. arcuatus, and 7.80 in $E$. ensis. The range in proportions within each species is such, however, that there is some overlap between the species. In E. siliqua the shell tends to broaden in larger sizes, in E. arcuatus it remains fairly constant, whereas in E. ensis there is a tendency for it to become narrower.

Ford (I925) found a difference in the proportions of very small specimens of E. ensis and E. arcuatus. (He does not state, however, at what point the shell breadth was measured.) In E. arcuatus ranging from 7.5 to $21.0 \mathrm{~mm}$. in length the mean ratio was $5^{\circ} 08$, and in E. ensis ranging from $5^{\circ} 0$ to $22.5 \mathrm{~mm}$. the mean ratio was $6 \cdot 44$. Here again there was some overlap between the two species.

Thus the length/breadth ratio is not a reliable distinguishing character where only a few specimens from a population are available.

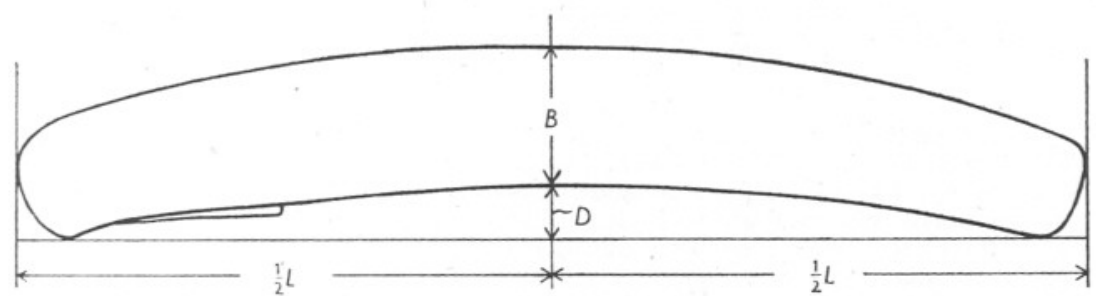

Text-fig. 2. Method of measuring breadth $(B)$ and curvature $(D)$ of an Ensis shell.

Curvature. The most obvious difference between the species is in the shell curvature. A measure of the curvature of the dorsal edge of the shell is obtained as shown in Text-fig. 2. The dorsal edge of a single valve is placed against a straight edge on a special measuring board, so that the two ends touch the edge. The ligament is cut away as necessary to allow this. In $E$. siliqua the shell usually touches at the anterior end and at a point just behind the mid-region, as the shell is often slightly convex on the dorsal surface. The distance $B+D$ is measured by a vernier calliper, as is the breadth $(B)$. ' $D$ ' is then obtained by subtraction.

In E. siliqua most specimens are straight or slightly convex, (Text-fig. 4) giving a ' $D$ ' of zero. ' $D$ ' is not more than $0.1 \mathrm{~cm}$. in normal specimens. Two very small specimens show some degree of curvature; this results in a slight curvature in the hinge region in adult specimens.

In $E$. arcuatus curvature is variable, some being as straight as slightly curved specimens of $E$. siliqua.

In E. ensis curvature is greater than in E. arcuatus, the plots of the two species scarcely overlapping.

It will be noticed that ' $D$ ' becomes proportionately greater in large specimens. This is to be expected if the shells are growing in a curve approximating 


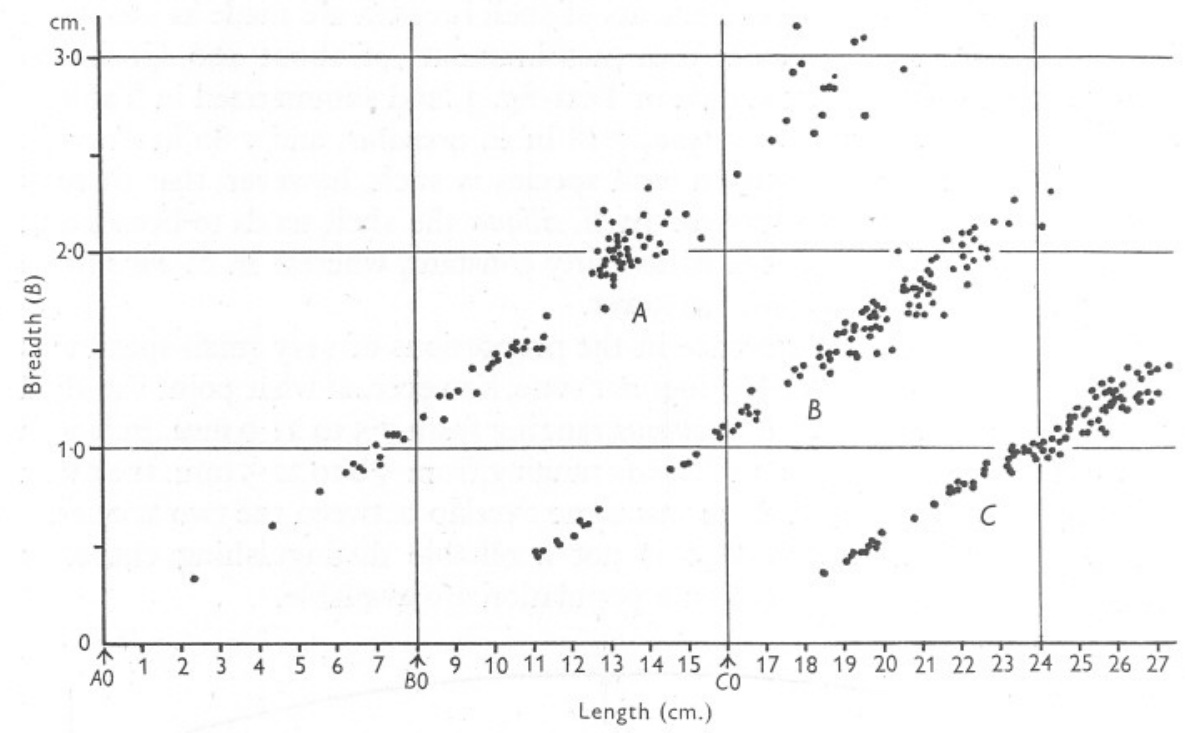

Text-fig. 3. Length-breadth relations of shells of Ensis: $A$, E. siliqua, 95 specimens from Broadsands, Torbay (6); Dale Roads, Milford Haven (6); Helford river, Cornwall (3); Millport (9); Paignton (59); Polesands, Exmouth (7); Salcombe (5). B, E. arcuatus, I 2 specimens from Derbyhaven, Isle of Man (4); Eddystone shell-gravel (I); Grouville Bay, Jersey (10); Mewstone shell-gravel, Plymouth (I); Millport (3); Newton Haven, Northumberland (2); Salcombe, (52); Tresco, Scilly Is. (I6); Yealm river (23). C, E. ensis, IOI specimens from Broadsands, Torbay (6); washed up on Dawlish Warren Beach (44); Grouville Bay, Jersey (5); St Aubin's Bay, Jersey (26); Salcombe (20). All shells are from material collected alive, except for some of those from Dawlish Warren Beach.

Note that the plots of $A, B$ and $C$ have different origins (indicated by arrows).

\section{TABLE I}

\begin{tabular}{|c|c|c|c|c|c|}
\hline & & & & gth/breadth & tio \\
\hline & (cm.) & examined & Mean & Maximum & Minimum \\
\hline E. siliqua & $0-4.0$ & I & $7 \cdot 06$ & $\div$ & $\overline{608}$ \\
\hline & $4 \cdot I-8 \cdot 0$ & I3 & $7 \cdot 09$ & $7 \cdot 72$ & $6 \cdot 28$ \\
\hline & $8 \cdot \mathrm{I}-\mathrm{I} 2 \cdot \mathrm{O}$ & $2 \mathrm{I}$ & $7 \cdot 06$ & $7 \cdot 54$ & $6 \cdot 74$ \\
\hline & $\mathrm{I} 2 \cdot \mathrm{I}-\mathrm{I} 6 \cdot \mathrm{O}$ & 44 & 6.67 & $7 \cdot 50$ & $5 \cdot 84$ \\
\hline & $>16 \cdot 0$ & I6 & 6.55 & $7 \cdot 26$ & 5.66 \\
\hline & All sizes & 95 & $6 \cdot 80$ & $7 \cdot 72$ & $5 \cdot 66$ \\
\hline E. arcuatus & $0-4.0$ & 6 & $6 \cdot 92$ & $7 \cdot 16$ & 6.49 \\
\hline & $4 . \mathrm{I}-8.0$ & I2 & $7 \cdot 23$ & $7 \cdot 61$ & 6.65 \\
\hline & $8 \cdot I-I 2 \cdot 0$ & 46 & $7 \cdot 20$ & $8 \cdot 29$ & $6 \cdot 7 \mathrm{I}$ \\
\hline & $\mathrm{I} 2 \cdot \mathrm{I}-\mathrm{I} 6 \cdot 0$ & 46 & $7 \cdot 17$ & $8 \cdot 17$ & $6 \cdot 20$ \\
\hline & > I6.0 & 2 & $7 \cdot 32$ & $7 \cdot 56$ & 7.08 \\
\hline & All sizes & II 2 & $7 \cdot 18$ & $8 \cdot 29$ & $6 \cdot 20$ \\
\hline E. ensis & $0-4.0$ & II & $7 \cdot 20$ & $7 \cdot 64$ & $6 \cdot 83$ \\
\hline & $4 . I-8 \cdot 0$ & 28 & $7 \cdot 66$ & $8 \cdot 39$ & $7 \cdot 20$ \\
\hline & $8 \cdot I-12 \cdot 0$ & 62 & 8.01 & 9.07 & $7 \cdot 25$ \\
\hline & All sizes & IOI & $7 \cdot 80$ & 9.07 & $6 \cdot 83$ \\
\hline
\end{tabular}




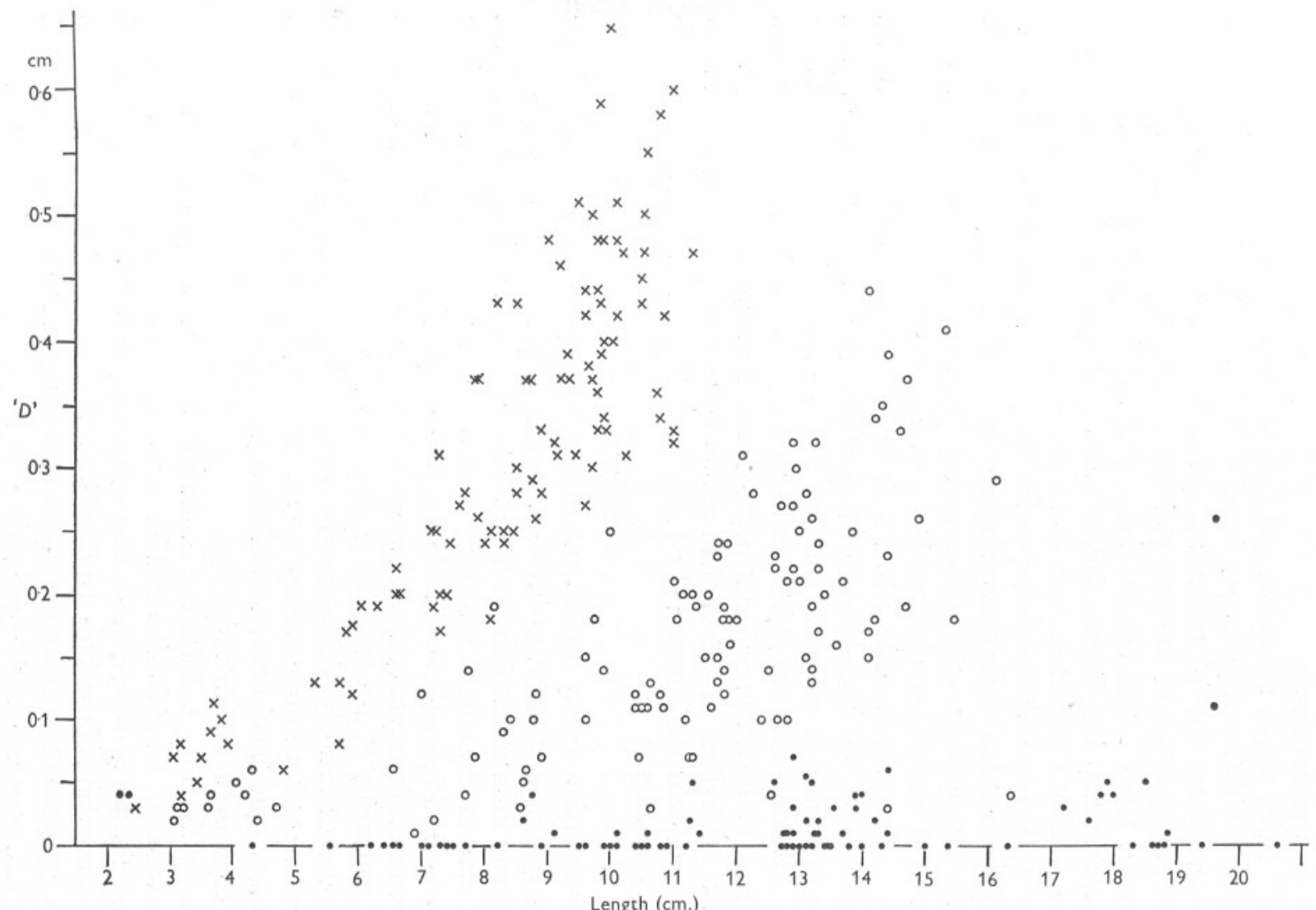

Text-fig. 4. Measurements of shell curvature (' $D$ ', Text-fig. 2) against shell length. The shells are those used for breadth measurements in Text-fig. 3. $\times$, E. ensis; 0 , E. arcuatus; $\bullet$, E. siliqua. 
to an arc of a circle. The points would then form part of an ellipse, the proportions of which would naturally vary according to the scale adopted for the two axes of the graph.

Taper. In E. siliqua the dorsal and ventral edges are almost parallel, with little taper at either end (Text-fig. I and Pl. I, fig. I). In E. arcuatus there is some slight taper at the posterior end. In $E$. ensis, however, the ventral edge approaches the dorsal in the posterior third of the shell, producing a most pronounced taper. Although no measurements of taper have been made it would appear that the degree of taper in extreme specimens of E. arcuatus is similar to that of a typical $E$. ensis, and vice versa.

Shape of the ends. The posterior end of the shell in all three species is truncated, that of $E$. ensis being if anything a little more rounded than in the other two. The anterior ends of $E$. siliqua and $E$. arcuatus are similarly truncated, but that of $E$. ensis is rounded, as shown in Text-fig. I.

Colour. The outside of the shell is divided diagonally into two areas of a different colour. The dorsal area is white or liver-coloured, while the ventral area varies from pale yellow to chestnut brown in colour. E. ensis is usually lighter in colour than the other species, but all shades from yellow to dark brown may be found in different populations of all three species. Small individuals are lighter in colour than adults from the same locality, and are often spotted with dark brown (Pl. I, fig. 2). The spots disappear or become indistinct in adults.

\section{Soft Parts}

Bloomer (I90I-2) has studied the anatomy of E. ensis and E. siliqua. He found only minor differences between them, of little value in identification. $\mathrm{Mr}$ Bloomer informs me that his specimens were obtained from the Specimen Department at Plymouth. Since E. ensis is rare at Plymouth, most of the records in the Plymouth Marine Fauna (Marine Biological Association, I93I) being incorrect identifications of $E$. arcuatus, it seems possible that Bloomer was in fact comparing $E$. arcuatus, not $E$. ensis, with $E$. siliqua.

The internal anatomy of Ensis has not been examined in any great detail. The gross anatomy of all three species is very similar. Sections of the gills failed to show any significant differences in structure. Two characters have, however, been found useful for identification.

Colour of the foot. A difference in the colour of the foot has been noted by several authors. In $E$. siliqua and $E$. arcuatus it is creamy white in colour, reticulated with fine brown lines. The colour varies with the degree of distension or contraction of the foot. In $E$. ensis the foot is a pale reddish brown, and is also reticulated. The difference in colour is not great, but is useful in sorting out a mixed population of $E$. ensis and $E$. arcuatus.

The fourth aperture. In the posterior half of the body the mantle edges are fused ventrally, but anteriorly fusion is very weak, so that the mantle folds may be readily separated back as far as a small opening, the fourth aperture 
(Texı-fig. 5,A). The weak fusion is brought about by a cuticular junction of the mantle edges (Atkins, I937).

Yonge (I948) believes the aperture to be a 'safety valve which permits the ventral extrusion of some of the water in the mantle cavity when these rapidly burrowing animals make the sudden muscular contractions involved in downward movement'.

The aperture is bordered by a row or rows of papillae, which interdigitate when the shell is closed. The papillae occur in about equal numbers on each side of the aperture. There is considerable variation in the number of papillae in each species, but $E$. siliqua tends to have more than the other two:

E. siliqua. Thirty-four specimens from Paignton, Devon. Number of papillae on one side of the opening: mean, 20.9; maximum, 40; minimum, 9.

E. arcuatus. Forty-two specimens from Tresco, Scilly Isles. Mean, I0.5; maximum, 26; minimum, 5 .

E. ensis. Twelve specimens from St Aubin's Bay, Jersey. Mean, I2.0; maximum, I5; minimum, 8.

The species differ more in the form than in the number of papillae. In E. siliqua the papillae occur in more than one row, in a staggered arrangement. In small specimens they are simple (Text-fig. 5, G) but in those over about $7 \mathrm{~cm}$. in length they are branched, or compound (Text-fig. 5, B, E and F). In side view they often resemble molar teeth. The form of the papillae can be distinguished with a lens in living specimens. Those illustrated in Textfig. 5 are preserved in alcohol; the papillae do not seem to contract to any great extent in preserved specimens.

In E. arcuatus the papillae are simple, and in a single row (Text-fig. 5, H, I). Rarely, in large specimens, they may become bifid or club-shaped, but never assume the compound form typical of $E$. siliqua.

In $E$. ensis the papillae are similar to those of $E$. arcuatus (Text-fig. 5, J, K).

The form of the papillae of the fourth aperture is the only certain method of distinguishing adult specimens of $E$. siliqua and $E$. arcuatus. Certain separation is more difficult where specimens are still too small to show differences in these papillae, but the curvature of the shell is often some guide.

\section{VALIDITY OF THE SPECIES}

Constant morphological differences have been found between the three species of Ensis. These differences are slight however, and might be attributable to the effect of environment on a single species. E. siliqua occurs in clean sand at L.W.S.T., extending a little below extreme low-water mark. E. arcuatus lives in coarse sand or fine gravel at L.W.S.T., and extends out into deeper water. $E$. ensis inhabits bottoms of fine, sometimes slightly muddy, sand; rarely occurring on the shore. Thus the three species are not often found living together. 


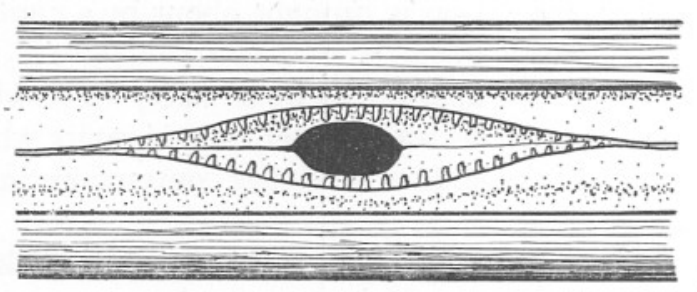

A
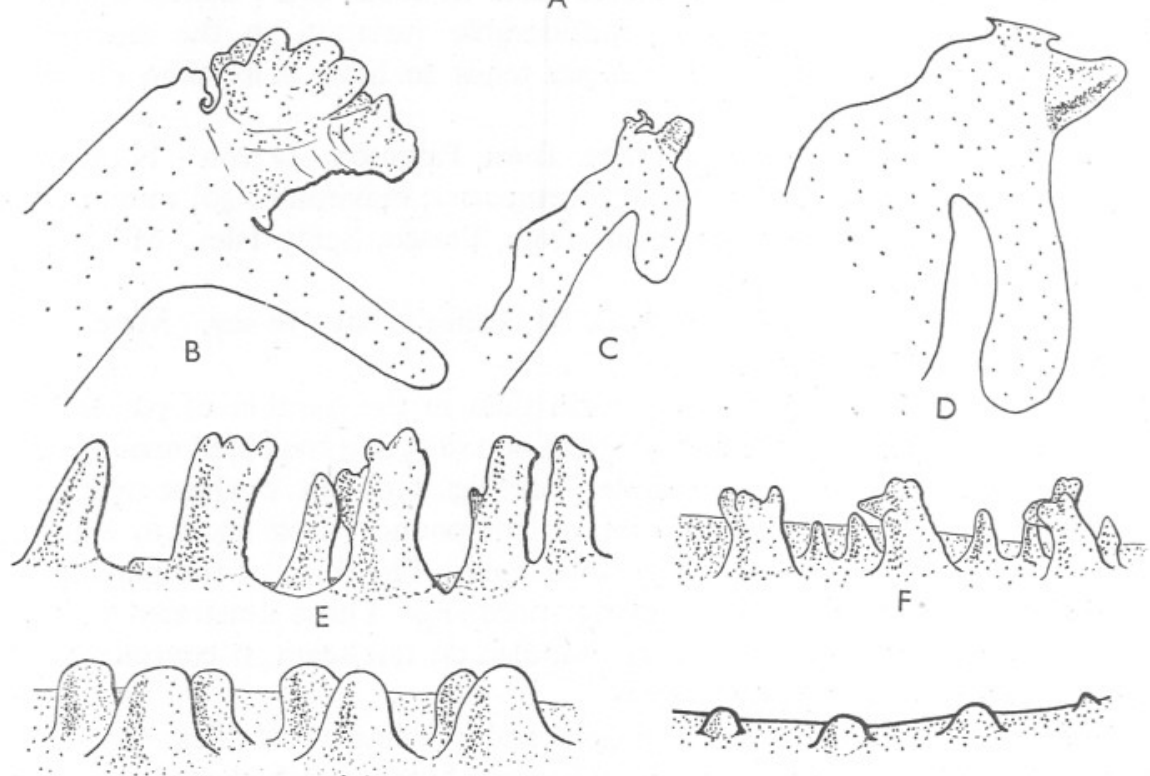

G

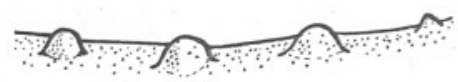

।

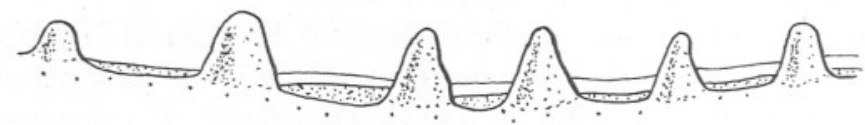

$\mathrm{H}$

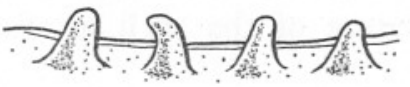

J

Text-fig. 5. Morphology of the fourth aperture. A, ventral view of the aperture in E. siliqua, $\times 4$. The shell is shown slightly gaping to reveal the mantle folds surrounding the opening. The anterior end is to the left. B-D, thick sections through the edge of the mantle opposite the aperture, the latter being on the right of the lip (lower right). A papilla (compound in $E$. siliqua) is shown top right. B, E. siliqua; C, E. ensis; D, E. arcuatus. All are $\times$ I9.5. $\mathrm{E}-\mathrm{K}$, papillae viewed from inside the aperture, looking outwards: E, E. siliqua, length I5.0 cm., $\times$ I9.5; F, E. siliqua, length $13.7 \mathrm{~cm} ., \times$ I9.5; G, E. siliqua, length $7.0 \mathrm{~cm} ., \times 59$; $\mathrm{H}$, E. arcuatus, length $14.75 \mathrm{~cm} ., \times 19.5$ (all papillae on one side shown); I, E. arcuatus, length $7.9 \mathrm{~cm} ., \times 19.5 ; \mathrm{J}, E$. ensis, length $10.05 \mathrm{~cm} ., \times 19.5 ; \mathrm{K}, E$. ensis, length $4.52 \mathrm{~cm}$. $\times 19.5$. 


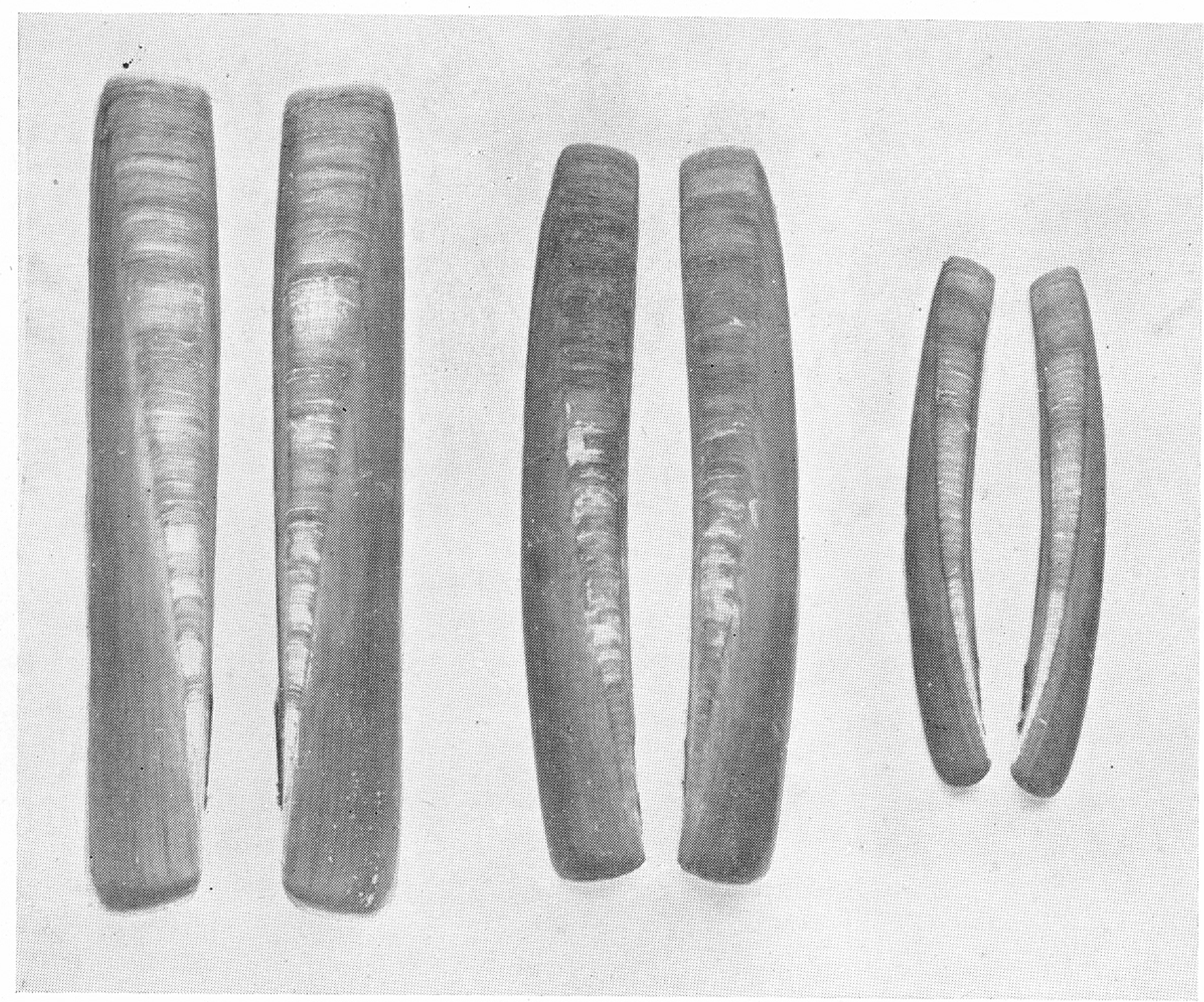

Fig. I. Shells of adult Ensis. $\times 0 \cdot 47$. Left to right: E. siliqua, E. arcuatus, E. ensis.

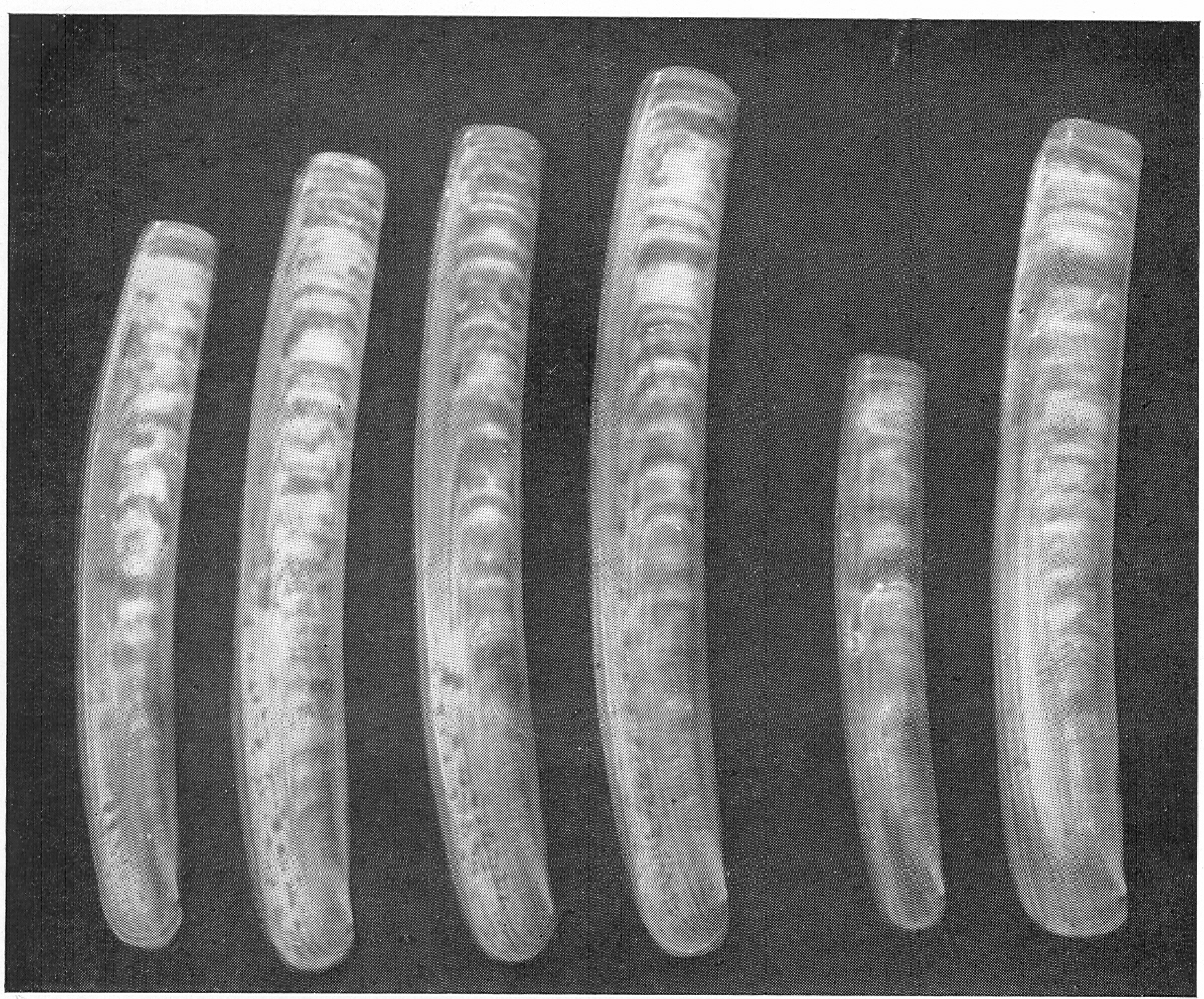

Fig. 2. Small individuals of Ensis. $\times 2 \cdot 4$. Left: four specimens of E. ensis dredged in Whitsand Bay. Right: two specimens of $E$. arcuatus from the same locality. The foot may be seen projecting beyond the end of the shell in some of the specimens. 
Occasionally, however, mixed populations have been found living in the same grade of soil in one locality. The following instances have been recorded:

$E$. siliqua living with $E$. ensis: Broadsands, Torbay, in fine sand.

$E$. siliqua living with $E$. arcuatus: south side of Millbay, Salcombe, in fine sand; Jeffreys (I863) records both species from Belgrave Bay, Jersey.

$E$. arcuatus living with $E$. ensis: in sand in St Aubin's Bay and Grouville Bay, Jersey, in Whitsand Bay, and in coarse muddy sand at Millbay, Salcombe.

Since the three forms maintain their distinctive characters when living together, it seems probable that they are separate species.

\section{SUMMARY}

The diagnostic characters of the British species of Ensis are described. The shell remains the primary means of identification, but additional characters in the soft parts are necessary for certain recognition. The three forms of Ensis described are considered to be valid species.

\section{Table II. Summary of Distinguishing Characters}

\begin{tabular}{|c|c|c|c|}
\hline & E. siliqua & E. arcuatus & E. ensis \\
\hline Length of shell & $20 \mathrm{~cm}$ & I5 $\mathrm{cm}$ & IO $\mathrm{cm}$ \\
\hline Shell curvature & Straight & Slightly curved & More curved than in $E$. arcuatus \\
\hline Taper of posterior end & None & Slight & Marked taper \\
\hline Anterior end & Truncated & Truncated & Rounded \\
\hline Foot colour & Cream-white & Cream-white & Pale red-brown \\
\hline $\begin{array}{l}\text { 4th aperture: } \\
\text { Rows of papillae }\end{array}$ & Staggered & I row & I row \\
\hline Shape of papillae & Compound & Simple & Simple \\
\hline
\end{tabular}

\section{REFERENCES}

AtкINs, D., I937. On the ciliary mechanisms and interrelationships of lamellibranchs. Part IV. Cuticular fusion, with special reference to the fourth aperture in certain lamellibranchs. Quart. Fourn. Micr. Sci., Vol. 79, pp. 423-45.

Bloomer, H. H., I90I-2. The anatomy of the British species of the genus Solen Linné. Parts I-III. Fourn. Malacol., Vol. vIII, pp. 36-46, pp. 97-I00; Vol. IX, pp. I8-2I.

Forbes, E. \& Hanley, S., 1853. A History of the British Mollusca and their Shells. 4 vols. London.

ForD, E., 1925. On the growth of some lamellibranchs in relation to the food-supply of fishes. Fourn. Mar. Biol, Assoc., Vol. xiII, pp. 53I-59.

Jefrereys, J. G., 1863. British Conchology, or an Account of the Mollusca which now Inhabit the British Isles and the Surrounding Seas, Vol. II, 465 pp. London.

Marine Biological Association, 1931. Plymouth Marine Fauna. (2nd ed.).

Sowerby, G. B., I887. Illustrated Index of British Shells, and ed. London.

Winckworth, R., I932. The British marine Mollusca. fourn. Conch. Vol. I9, pp. 2 I I52.

YoNGE, C. M., I948. Cleansing mechanisms and the function of the fourth pallial aperture in Spisula subtruncata (da Costa) and Lutraria lutraria (L.). Fourn. Mar. Biol. Assoc., Vol. xxvII, pp. 585-96. 